\title{
Case Report: Severe acute respiratory distress by tracheal \\ obstruction due to a congenital thyroid teratoma: a case
}

\section{report and literature review. [version 1; peer review: awaiting}

\section{peer review]}

Jose Colleti Junior ${ }^{1}$, Uenis Tannuri², Felipe Monti Lora ${ }^{3}$, Eliana Carla Armelin Benites ${ }^{4}$, Walter Koga1, Janete Honda Imamura1, Patricia Rute Moutinho1, Werther Brunow de Carvalho1

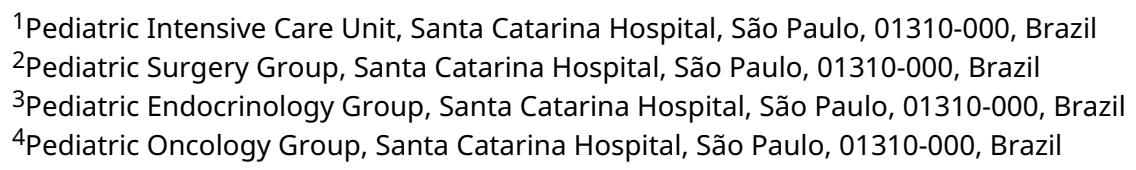

V1 First published: 22 Jun 2015, 4:159

https://doi.org/10.12688/f1000research.6589.1

Second version: 23 Jul 2015, 4:159

https://doi.org/10.12688/f1000research.6589.2

Latest published: 22 Oct 2015, 4:159

https://doi.org/10.12688/f1000research.6589.3

\section{Abstract}

Congenital teratoma is a rare condition and is a germ cell tumor composed of elements from one or more of the embryonic germ layers and contain tissues usually foreign to the anatomic site of origin. We report a case of a neck tumor diagnosed during pregnancy, initially thought to be a goiter. After birth the neck mass kept growing until it compressed the trachea and produced respiratory failure. The infant had a difficult tracheal intubation because of the compressing mass. The staff decided to surgically remove the neck mass. After that, the infant became eupneic. The histological analysis showed a mature teratoma with no atypias.

\section{Keywords}

thyroid teratoma, pediatric neck mass, pediatric respiratory distress, hypothyroidism, children case report

\section{Open Peer Review \\ Approval Status} 2

version 3

(revision)

22 Oct 2015

version 2

(revision)

23 Jul 2015

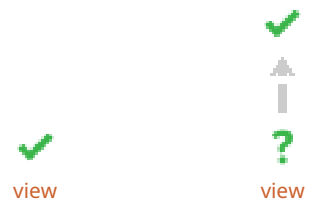

version 1

22 Jun 2015

1. Francisco Eulógio Martinez, University of São Paulo, Ribeirão Preto, Brazil

Walusa Assad Gonçalves-Ferri, University of São Paulo, Ribeirão Preto, Brazil

2. Daniel Garros, Stollery Children's Hospital, Edmonton, Canada

Any reports and responses or comments on the article can be found at the end of the article. 
Corresponding author: Jose Colleti Junior (colleti@gmail.com)

Competing interests: The authors declare that they have no competing interests.

Grant information: The author(s) declared that no grants were involved in supporting this work.

Copyright: $\odot 2015$ Colleti Junior J et al. This is an open access article distributed under the terms of the Creative Commons Attribution License, which permits unrestricted use, distribution, and reproduction in any medium, provided the original work is properly cited.

How to cite this article: Colleti Junior J, Tannuri U, Monti Lora F et al. Case Report: Severe acute respiratory distress by tracheal obstruction due to a congenital thyroid teratoma: a case report and literature review. [version 1; peer review: awaiting peer review] F1000Research 2015, 4:159 https://doi.org/10.12688/f1000research.6589.1

First published: 22 Jun 2015, 4:159 https://doi.org/10.12688/f1000research.6589.1 


\section{Introduction}

Congenital thyroid teratoma is a rare condition ${ }^{1,2}$. We report a case of an infant with a neck mass diagnosed by ultrasound during pregnancy which was initially supposed to be a congenital goiter. Two doses of levothyroxine were administered into the amniotic fluid. The goiter kept growing after birth until it caused severe respiratory distress by compressing the trachea, necessitating immediate tracheal intubation. The tumor was surgically resected and the patient went eupneic for the first time in his life. The histological analysis demonstrated a mature teratoma with no atypias. Thyroid hormone substitute therapy was started and the infant is thriving well.

\section{Case report}

A 2-months-and-20-days-old Brazilian white male infant weighing $4.2 \mathrm{~kg}$ was admitted to the pediatric intensive care unit of our hospital (Santa Catarina Hospital, São Paulo, Brazil) in acute respiratory distress and was immediately intubated and placed in mechanical ventilation.

From a routine ultrasound during pregnancy, the fetus had been diagnosed with a cervical mass, considered initially to be a goiter (Figure 1) by doctors at another institution. Family history of the mother uncovered a cousin with hypothyroidism. The mother was previously healthy, but after diagnosis of the cervical mass of the fetus, she was tested for thyroid hormones and had hypothyroidism diagnosed during pregnancy (TSH: $5.0 \mathrm{mUI} / \mathrm{mL}$ - normal: 0.2 to $3.0 \mathrm{mUI} / \mathrm{mL}$; free T4: $0.7 \mathrm{ng} / \mathrm{dL}$ - normal: 0 . To $1.3 \mathrm{ng} / \mathrm{dL}$; antithyroglobulin antibodies: $65 \mathrm{U} / \mathrm{mL}$ - normal: inferior to $60 \mathrm{U} / \mathrm{mL}$ and thyroid antiperoxidase antibodies: $166 \mathrm{UI} / \mathrm{mL}$ - normal: inferior to $9 \mathrm{UI} / \mathrm{mL}$ ). Two single doses of $200 \mu \mathrm{g}$ of levothyroxine were administered into the amniotic fluid, one during the 28th and one during the 31 st week of pregnancy, in order to treat the supposed fetal thyroid hormone deficiency. Chorioamnionitis appeared after the second levothyroxine administration which triggered a premature cesarean birth which was undertaken in the other hospital. The premature newborn had sepsis due to maternal infection (chorioamnionitis) and remained in mechanical ventilation for 10 days. After tracheal extubation, he remained in nasal continuous positive airway pressure (CPAPn) for 7 more days, and after that was kept on oxygen therapy for 10 days. He was discharged from the hospital 50 days after birth, still presenting with a laryngeal stridor that was attributed to tracheal malacia by the doctors that initially treated the patient.

After hospital discharge, he was observed by a pediatric endocrinologist who started research on thyroid disorders. Meanwhile, the infant maintained a euthyroid state, receiving no treatment, waiting for more investigation on the cause of the neck mass. However, the cervical mass kept visibly growing, was palpable and the infant presented a laryngeal stridor that was still attributed, by the pediatrician who followed the infant, to laryngomalacia. In the few days preceding hospitalization at our institution, the infant became increasingly dispneic each day, as related by his mother. One day, after choking and vomiting during breastfeeding he became hypotonic and went into acute respiratory distress.

He was admitted to our pediatric intensive care unit 25 days after he had been discharged from the other hospital, and was immediately intubated. An X-ray showed a small amount of interstitial infiltrate, compatible with aspiration pneumonia. However, the respiratory distress was attributed mainly to an upper airway obstruction. It was difficult to tracheally intubate the infant; only an uncuffed $2.5 \mathrm{~mm}$ endotracheal tube (ETT) was able to be inserted into the trachea and it was difficult to place this in the right position. The X-ray after intubation showed the ETT in a high position and the trachea displaced to the right (Figure 2). Magnetic resonance imaging (MRI) revealed the extent of the cervical mass and its compression on the trachea, and the latter's subsequent displacement (Figure 3a and 3b).

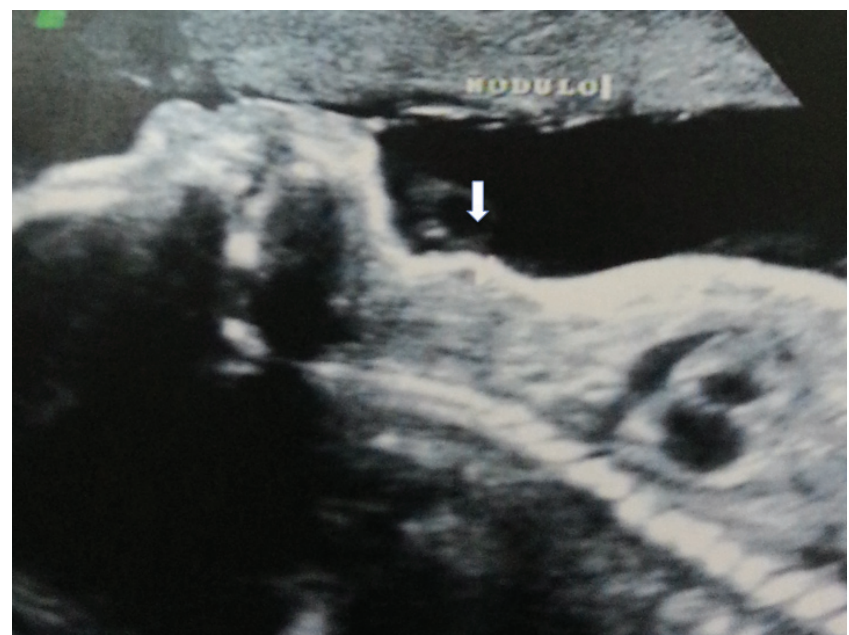

Figure 1. Prenatal ultrasound showing the neck mass.

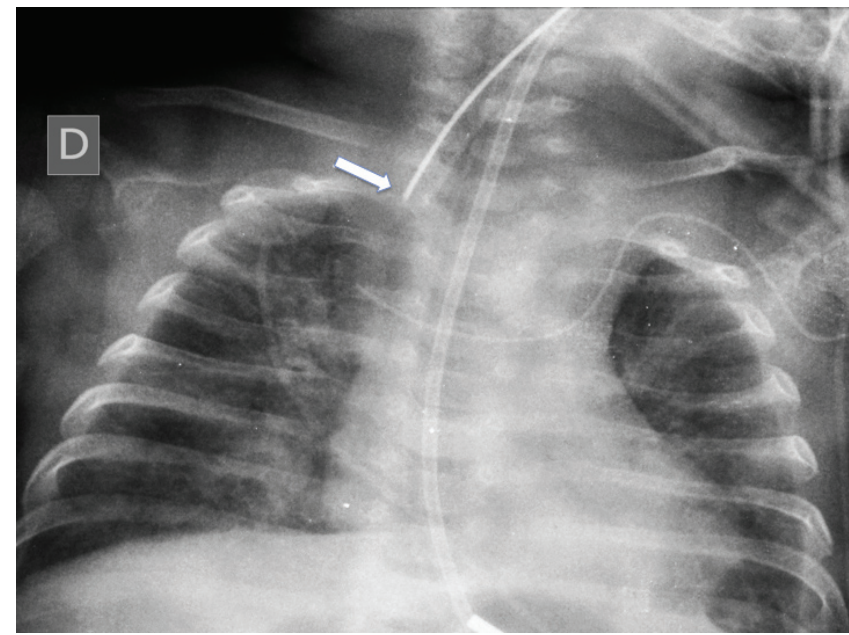

Figure 2. Endotracheal tube displaced to the right position. 

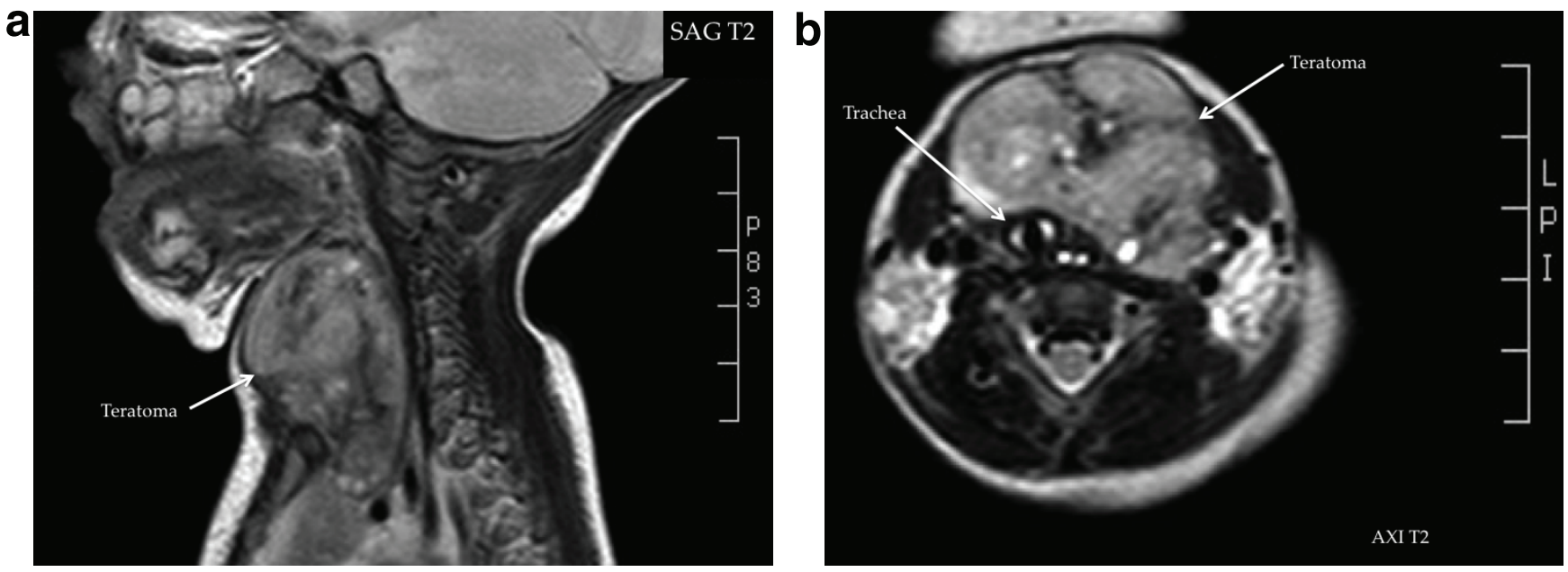

Figure 3. a. Sagittal MRI (T2) of the neck showing the teratoma. Axial MRI (T2) of the neck showing the teratoma and the tracheal displacement

Meanwhile, we started investigation into the cause of the neck mass and performed blood tests on the infant: thyroid hormones were in the normal range (free thyroxine (T4): $1.3 \mathrm{ng} / \mathrm{dL}$ and thyroidstimulating hormone (TSH): $4.7 \mathrm{ng} / \mathrm{dL}$ ). Calcitonin levels, for investigations into potential malignance, were normal (calcitonin: $21 \mathrm{pg} / \mathrm{mL}$ ), as was the alpha-fetoprotein: $505 \mu \mathrm{g} / \mathrm{L}$.

We decided to remove the cervical mass, since it was causing the tracheal obstruction. The surgery lasted 35 minutes and was uneventful. The mass was well circumscribed and could be easily dissected, weighed 20 grams and measured $33 \times 61 \times 45 \mathrm{~mm}$ (Figure 4). The infant returned from surgery in good condition. A bronchoscopy was performed the next day after surgery, during tracheal extubation, which revealed no malacia or any other disorders on the trachea or the upper respiratory tract. The patient has been eupneic since then. The histological analysis revealed a mature teratoma with no atypias or signs of malignancy.

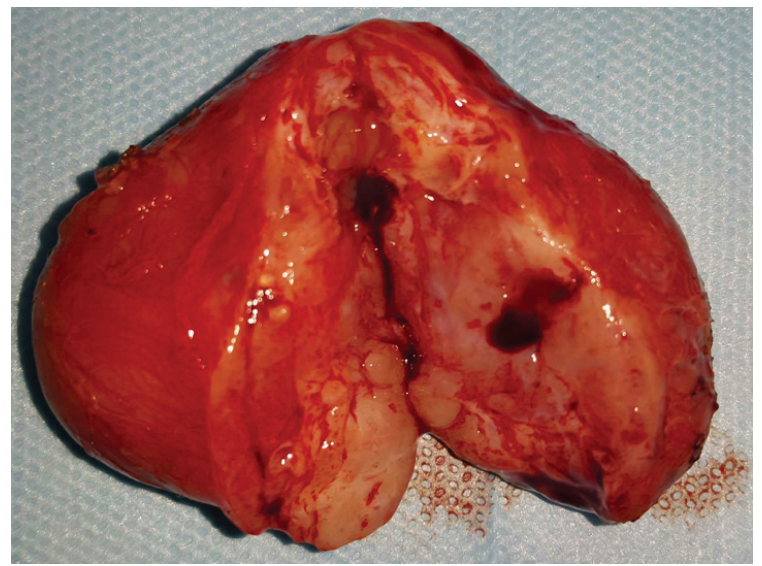

Figure 4. The resected benign teratoma.
Levothyroxine was started ( $25 \mu \mathrm{g}$, once a day) as thyroid hormone substitute therapy and the infant is thriving well according to the pediatric endocrinologist that continues following the patient.

\section{Discussion}

Teratomas originate from multipotent primitive germ cells and result in different tissues, diverging from the anatomical site of origin $^{2,3}$. They are most common during early childhood and the most common location is the sacrococcygeal region in children and the gonadal region in adults ${ }^{2-4}$. The frequency of these embryonic tumours is about 1:20,000-40,000 live births. However, only $1.5 \%$ to $5.5 \%$ of all pediatric teratomas are placed in the neck region. These tumours are usually solitary, with no other associated congenital malformations or chromosomal abnormalities ${ }^{4}$. Although $95 \%$ of all teratomas are benign, the cervical teratomas if not properly treated, lead to death in $80 \%$ of the cases due to obstructive respiratory distress ${ }^{3-5}$.

In this case, the acute clinical presentation of the neck mass with severe respiratory distress, needing ready intervention and immediate tracheal intubation should alert all pediatricians to the risk of these neck masses, and consider it as a potentially fatal case. In the presented case, surgical removal of the neck mass was both diagnostic and therapeutic.

\section{Conclusion}

Thyroid teratoma is rare in infants, it is usually benign, and can cause airway compression depending on the site and size of the mass. The likelihood of a malignant thyroid teratoma is low in infants, however it could be fatal by causing upper airway obstruction. Therefore, surgical resection is required both for diagnosis and treatment. If the surgical removal is a success, the long-term outcome and quality of life should be good ${ }^{5}$. 


\section{Consent}

Written informed consent was obtained from parents of the patient for publication of this case report and any accompanying images. A copy of the written consent is available for review by the editor of this journal.

Author contributions

JCJ drafted the first manuscript. UT is the pediatric surgeon and helped with the decision of resecting the tumor. FML did the endocrinological research and helped with the draft. ECB is from the pediatric oncology team and helped with the diagnosis and the draft. WK, JHI and PRM contributed to treating the patient. WBC revised and edited the manuscript. All authors have read and approved the content of the final manuscript.

Competing interests

The authors declare that they have no competing interests.

\section{Grant information}

The author(s) declared that no grants were involved in supporting this work.
1. Oak CY, Kim HK, Yoon TM, et al:: Benign teratoma of the thyroid gland. Endocrinol Metab (Seoul). 2013; 28(2): 144-8.

PubMed Abstract | Publisher Full Text | Free Full Text

2. Hasiotou M, Vakaki M, Pitsoulakis G, et al.: Congenital cervical teratomas. Int $J$ Pediatr Otorhinolaryngol. 2004; 68(9): 1133-9. PubMed Abstract | Publisher Full Text

3. Fichera S, Hackett $\mathrm{H}$, Secola R: Perinatal germ cell tumors: a case report of a cervical teratoma. Adv Neonatal Care. 2010; 10(3): 133-9.

PubMed Abstract | Publisher Full Text
4. Kocarslan S, Dorterler ME, Koçarslan A, et al:: Asymptomatic cervical mature teratoma in a child: an unusual presentation. J Clin Diagn Res. 2015; 9(2): EL01-2.

PubMed Abstract | Publisher Full Text | Free Full Text

5. Sheikh F, Akinkuotu A, Olutoye $O O$, et al.: Prenatally diagnosed neck masses: long-term outcomes and quality of life. J Pediatr Surg. 2015; 50(7): 1210-3.

PubMed Abstract | Publisher Full Text 
The benefits of publishing with F1000Research:

- Your article is published within days, with no editorial bias

- You can publish traditional articles, null/negative results, case reports, data notes and more

- The peer review process is transparent and collaborative

- Your article is indexed in PubMed after passing peer review

- Dedicated customer support at every stage

For pre-submission enquiries, contact research@f1000.com 